\title{
INVESTIGATING THE POTENTIAL IMPACT OF LITTLE FIRE ANT (LFA), Wasmania auropunctata (Roger) (Hymenoptera: Formicidae) ON THE OIL PALM POLLINATING WEEVIL, Elaedobius kamerunicus FAUST. (Coleoptera: Curculionidae) AND FIELD WORKER PRODUCTIVITY TIME
}

\author{
ERO, M M*; DIKREY, R*; BATARI, T* and BONNEAU, L J G*
}

\begin{abstract}
The oil palm pollinating weevil (E. kamerunicus) is a million-dollar insect in the oil palm industry in terms of its role as the key pollinating agent. Any negative impact on the weevil population due to influence by either biotic or abiotic factors can potentially have dire consequences on palm oil production. The invasive little fire ant (LFA), W. auropunctata was detected on oil palm blocks in West New Britain Province in 2012. Its invasion into the oil palm fields poses a potential risk to the weevil as it can feasibly prey on the immature stages. A study was necessary to investigate this risk. Hence, a research was instigated in 2016 and conducted over 13 months period to evaluate the potential impact on the weevil population as well as the worker productivity time (because of the pain normally inflicted on humans by the sting) in smallholder blocks of the Hoskins Oil Palm Industry Corporation (OPIC) project within the West New Britain Province. The results showed that LFA does not impact on the pollinating weevil population but does affect field worker productivity time. Study investigating the management options to circumvent LFA stings is proposed.
\end{abstract}

Keywords: arboreal, invasive, male inflorescence, queen, smallholder.

Date received: 23 March 2019; Sent for revision: 11 April 2019; Accepted: 23 September 2019.

\section{INTRODUCTION}

Wasmania auropunctata (Roger), colloquially known as the little fire ant (LFA) or electric ant is an invasive ant native to South and Central America (Wetterer, 2013). However, the ant has spread and occupied most parts of the pan-tropical regions. It has been recorded from the USA (including Hawaii), Caribbean Islands, parts of the African continent, northern part of Australia (Cairns) and the Pacific Islands (Wetterer, 2013; Wetterer and Porter, 2003).

\footnotetext{
Papua New Guinea Oil Palm Research Association Dami Oil Palm Research Station, P.O. Box 97, Kimbe, West New Britain Province, Papua New Guinea.

E-mail: mark.ero@pngopra.com
}

The ant has also been detected in the Mediterranean region from Israel (Vonshak et al., 2009).

The worker ants and reproductive males are very small in size (about $1.5 \mathrm{~mm}$ long) and are light to golden brown in colour. The queens are slightly larger measuring about $4.5 \mathrm{~mm}$ in length. They are also wingless unlike queens of other species of ants. Mating between males and queens occur within the parent colony and fertilised queens either remain there or disperse on foot taking with them a small number of workers to care for them and the new brood which the queens will produce. Often the new nests remain connected with the parent colony and tasks of territory defence and food gathering are shared. Each colony has either a single or multiple 
queens. The loss of workers and even queens does not threaten the viability of the parent colony as the production of new workers and queens occurs frequently. Queens live up to a year and reproduce all year around. Approximately 1000-5000 worker ants per square metre can be found and these populations take about a month to develop (Foucaud et al., 2010). Natural spread by budding is relatively slow and occurs at rates measured in metres per year (about $3 \mathrm{~m} \mathrm{yr}^{-1}$ ). Human aid movement in planting materials and household items has been noted to be the common mode of spread over long distances (Vanderwoude, 2008).

LFA gains much of its energy needed for colony growth and dispersal by tending sugar producing insects (particularly scale insects, aphids and mealy bugs) in a symbiotic relationship. They obtain abundant supplies of carbohydrates from the sugar these insects secrete on plants (Wetterer and Porter, 2003). Although carbohydrate supply is abundant, protein supply needed for brood development and queen maintenance is usually low, subsequently limiting rapid colony growth.

The species is both ground dwelling and arboreal inhabiting mainly shady areas. The ants forage and nest in soil, vegetation and other structures, but their preferred habitat is in vegetation where they build small nests in any crack, crevice or hollow. Two distinct populations of the ant coexist within the native range in relation to habitat types. A low density and mostly sexually reproducing population exists in naturally undisturbed habitats whilst a high density, more dominant population occurs in a more disturbed environment (Orivel et al., 2009). The later population has an extraordinary reproductive system. Males are produced clonally, queens are parthenogenetic and workers are produced sexually (Fournier et al., 2005; Rey et al., 2013). It is the later population that is believed to have spread worldwide.

LFA poses threat to both biodiversity and human activities (Holway et al., 2002). The ants interfere with production in agricultural systems such as coffee and citrus where they promote scale insects as well as aphids and interfere with natural enemies (Fabres and Brown Jr, 1978). Once plantation workers disturb the ants on the crops they fall onto their body and sting them, particularly in softer parts of the body. The ants have also been found in crowns of mature coconut palms, making even harvesting of this crop difficult and painful. Whilst stings are only moderately painful to adults, children appear to be much more sensitive and are often stung multiple times in their sleep. They also nest in houses and rest places putting them in direct contact with people. They spoil foods in kitchens, and take over other ant species and native fauna. There is also anecdotal evidence that the ants sting domestic and wild animals, especially in the eyes, causing permanent blindness, and death of juvenile stages in some cases.

It is the worker ants that sting. The worker ants are sterile females that are incapable of reproducing. The ovipositor is modified into a venom gland which is used for the sting. The venom contains alkaloids and proteins. The alkaloids contain the piperidine toxin which kills the cells at the site of injection. It is the killing of the cells in the skin that causes the burning sensation and the pain (Howard et al., 1982; Showalter et al., 2010). The protein component has little or no effect at all during sting but can cause allergic reaction to people who are sensitive to proteins, and this situation can sometimes be fatal. They only sting when being disturbed. They are predaceous in feeding habit, but can also feed on nuts.

For Papua New Guinea (PNG), the insect was first intentionally introduced into the Autonomous Region of Bougainville in the 1970s as a biological control agent of the fruit spotting bug Amblypelta lutescens Distant on coconuts when its negative impacts were not fully understood. The introduced population has spread to almost all parts of the island and is now impossible to eradicate. In 2005, it was confirmed from Wewak and Yangoru in the East Sepik Province, which remained to be eradicated. There has also been an unconfirmed report of the incursion of the ant into Angoram District of the province. Since the East Sepik detection, it has been reported may have also spread to Madang and East New Britain Provinces (Vanderwoude, 2015). For the incursion in West New Britain Province, the detection of the ant was reported to the National Agriculture Quarantine and Inspection Authority (NAQIA) in 2012, but the species confirmation was not done until early 2015. Since then, the ant has invaded many smallholder blocks and some milling company oil palm plantations.

LFA does not impact directly on oil palm production. The ant does promote aphids, scale insects and mealy bugs (homopteran pests) by tending them but these insects are not major pests of oil palm. However, there are two issues of concern for the industry that needed to be investigated. The first concern is related to the loss of productivity time by field workers when attempting to stop the pain after being stung by the ants. The arboreal colonies nesting in the palm canopies dislodge when being disturbed during harvesting and drop down on workers stinging them. The sting normally causes burning sensation and is very painful. The ants crawl fairly quickly at a rate of around $1.6 \mathrm{~cm}$ $\mathrm{s}^{-1}$ when disturbed, and take around 10-20 s after climbing onto people for them to start stinging. One ant may sting several times leaving circular patterns normally with large number of them all stinging at the same time (Wetterer and Porter, 2003). The second concern was the impact it may have on the oil palm 
pollinating weevil E. kamerunicus Faust., which is a million-dollar insect to the oil palm industry. Due to the invasive nature, and the arboreal nesting and predatory feeding habit of the ant, it poses a potential risk of impacting on the weevil population from predation.

The study was conducted to investigate the potential impacts of $W$. auropunctata on pruningharvesting time of oil palm plantation workers and the pollinating weevil (E. kamerunicus) population through predation. Prior to monitoring pollinating weevil population to assess the impact of the ant on the weevil, diurnal movement of the ants was assessed to determine the existence of arboreal colonies. The results of the studies are presented and discussed.

\section{MATERIALS AND METHODS}

\section{Diurnal Behaviour Observations of LFA on Oil Palm for Potential Nesting Sites}

Due to the existence of both the arboreal and ground dwelling populations of the ant, a diurnal behavioural observation study was conducted in two oil palm fields with LFA infestation to determine the nesting habit of the population. The observations started from $0800 \mathrm{hr}$ and concluded at $1600 \mathrm{hr}$. Single ant trails were identified on individual palms and positions were marked with a permanent marker adjacent to the trails at chest height. The number of LFA moving about passing through the marked point during each hour within this period and the directions (i.e. either going up to the palm canopy or heading down to the ground) of their movements was recorded by having a staff positioned at the base of each palm. The counts were irrespective of the returning ants. The trial was replicated on 10 palms within an LFA infested block. Two palms were done per day for five days using two staff for recording.

\section{Floral Parts Census and the Pollinating Weevil Population Sampling}

Two smallholder blocks each with and without LFA infestation in the Hoskins Oil Palm Industry Corporation (OPIC) project were used for the study. The presence and absence of LFA was confirmed through protein baiting using peanut butter. The blocks were from Sarakolok in Nahavio Division and Siki in Siki Division. The blocks with LFA infestations were Block 003-884 and Block 0091055 respectively, whilst those blocks without LFA infestation were Block 003-831 and Block 009-599 respectively. Smallholder blocks are typically 2-6 ha in land area. At the standard planting density of 120 120 palms ha- ${ }^{-1}$, this covers $240-720$ palms. The study covered a monthly monitoring survey conducted from June 2016 to June 2017.

For the monitoring surveys, every second palm in every second row for 20 palms and five rows (total of 100 palms) was used. It covered a total of 10 rows and 400 palms (including the palms and rows skipped). At a planting density of 120 palms ha- ${ }^{-1}$, this covered approximately 3 ha of palm area. On each of the survey palm, census was conducted on anthesising male inflorescences, black fruit bunches, mixed bunches and aborted bunches. Average of each variable per hectarewas calculated using 120 palms ha ${ }^{-1}$ planting density. The census of the anthesising male inflorescence will show if the available male inflorescences are adequate to sustain enough weevil population for adequate pollination. The availability of consistently high number of black fruit bunches, and low mixed and aborted bunches would show that pollination has not been affected. Presence of high numbers of mixed and aborted bunches often result from inadequate pollination.

Apart from the census, five post anthesising male inflorescences were collected from each of the block and 10 spikelets each were collected randomly from different positions of the inflorescence after counting and recording the total number of spikelets. The spikelets were bundled and labelled according to inflorescence and block numbers. Once at the laboratory, each spikelet bundle was set up separately in individual rearing cages (BugDorm ${ }^{\mathrm{TM}}$ ) for adult weevil emergence. Once all weevils have emerged and died, the emergent weevils were counted and recorded according to site and treatment (i.e. infested or not infested). This data was then used to project the total pollinating weevil (E. kamerunicus) population per male inflorescence and extrapolated to per hectare.

\section{Evaluation of E. kamerunicus Immature Stage (egg, larva and pupa) Feeding by LFA}

Two sites with and without LFA (Control) infestation were selected at Dami Oil Palm Research Station (OPRS) for the setup of this trial. Prior to the trial set up protein baiting with peanut butter was done to confirm presence and absence of LFA. Once the trial sites were identified, three anthesising male inflorescences with E. kamerunicus adults were collected from Dami Oil Palm Plantation where there was no LFA infestation and set up in the laboratory for eggs to be laid. After the eggs were laid and more than half of the adult weevils had died, 300 spikelets were randomly drawn and bundled into 10 spikelets (a total of 20 bundles). Ten of the bundles were set up in an infested site whilst the other 10 were set up in an uninfested site. Each position was numbered 1-10 for each trial site. The remaining 10 bundles were set up in individual 
collapsible BugDorm ${ }^{\mathrm{TM}}$ - 6M610 cages (W60 x D60 x $\mathrm{H} 60 \mathrm{~cm}$ ) as a Control.

The exposure period went for 10 days. Ten days covered the immature stages duration period of the pollinating weevil. The spikelets were put out at $0700 \mathrm{hr}$ in the morning and retrieved at $1700 \mathrm{hr}$ in the afternoon and put into lunch box containers to prevent rats from feeding on them. They were put back the next morning to expose them to the ants.

After the 10 days exposure period, the spikelets from the field were taken back to the laboratory and set up for adult weevil emergence. After all the adults had emerged, they were counted and recorded according to treatment. The number of emergent adult weevils was used to determine the impact of LFA on the weevil.

Apart from placing male spikelets in the field, a direct feeding test was also done where pollinating larvae were directly exposed to the ants in the field. To attract the ants, small amounts of peanut butter used as protein bait were placed in 10 yellow screw cap sample bottles. Five peanut butter baited bottles were placed at the site infested with LFA whilst the remaining five were placed in locations free of LFA infestation. Five live larvae each taken from post anthesising male spikelets were placed in each of the sample bottles at both sites (i.e. LFA infested and not infested) and allowed for a day. They were put out at $0700 \mathrm{hr}$ in the morning and retrieved at around 1600 hr where they were taken back to the laboratory (with lids tightly sealed) for processing. The sample bottles from LFA infested sites were placed in the freezer overnight before they were processed. The next morning, the sample bottles were processed where the numbers of pollinating weevil larvae found in the vials were recorded.

\section{Impact of LFA Sting on Worker Productivity Time}

This study was conducted in a form of a questionnaire and concentrated among smallholder grower blocks with LFA infestation. The reason for concentrating the study with the smallholder growers was that they have consistent encounter with the ants in their blocks. The milling company plantation employees get to be moved around different fields therefore have limited encounter with the ants.

A total of 25 smallholder growers within the Hoskins OPIC project with LFA infestation in their oil palm blocks were interviewed. The questionnaires mainly focussed on the period of time taken by the growers to overcome the pain when stung and the measures taken to overcome the pain.

\section{Data Analysis}

Where data analysis was done, GenStat Data Analysis Software (19 ${ }^{\text {th }}$ Edition) was used.

\section{RESULTS AND DISCUSSION}

\section{Diurnal Behaviour Observation of LFA on Oil Palm for Potential Nesting Sites}

There was a significant difference in the number of LFA observed moving about in ant trails on the palm trunks at different times of the day $(F=5.84$, $\mathrm{P}<0.001)$. Significantly high numbers of ants were observed moving about at 0900 and $1000 \mathrm{hr}$ in the morning and 1300 and $1400 \mathrm{hr}$ in the afternoon (Figure 1). They were least active at $0800 \mathrm{hr}$ in the morning, 1100 and $1200 \mathrm{hr}$ at midday, and 1500 and $1600 \mathrm{hr}$ in the afternoon. The movements at most of the time during the observation period were in both directions (Table 1). There was no significant difference between the number of ants that were moving upwards and those that were moving downwards $(t=0.62, P$ $=0.27$ ). Despite the significant differences among the times of the day, the ants were generally active throughout the day with movements still observed during each hour of observation.

The movement by the worker ants in both directions of the palms has confirmed that the invading population is both arboreal and ground dwelling. The arboreal habit of the ants implies that they are potentially nesting within close proximity of the breeding substrates (anthesising male inflorescences) of the pollinating weevil. This potentially places the eggs and the larvae of the weevil at risk of being predated upon by the ant.

\begin{tabular}{lc}
\multicolumn{1}{l}{ TABLE 1. NUMBER OF ANTS (mean \pm SE) } \\
MOVING IN DIFFERENT DIRECTIONS
\end{tabular}

\section{Floral Parts Census and the Pollinating Weevil Population Sampling}

The mean number of male inflorescences counted per hectare from the four sites did not differ significantly $(F=0.7, P=0.56)$ among the sites. The infested sites had a mean of seven anthesising male inflorescences per hectare, whilst the blocks free of LFA infestation had 11 and 13 male inflorescences for Siki and Sarakolok, respectively (Figure 2a).

There was a significant difference in the number of black fruit bunches per hectare $(\mathrm{F}=4.6, \mathrm{P}=0.01)$. Those from both infested and non-infested blocks at Sarakolok were significantly high. The number of fruits from the infested block at Siki was significantly low whilst those from the non-infested block did not differ significantly from the rest of the blocks 
(Figure 2b). There was no clear pattern in the amounts of bunches counted between the infested and noninfested blocks.

The mean number of mixed fruit bunches counted did not differ significantly among the sites $(\mathrm{F}=1.5, \mathrm{P}=0.23)$. The non-infested block at Siki had 3 bunches ha ${ }^{-1}$ whilst the other three blocks had 1 bunch ha ${ }^{-1}$ (Figure 2c). No aborted fruit bunches were observed in all four blocks.

There was no significant difference in the mean number of pollinating weevils sampled per site $(\mathrm{F}=0.99, \mathrm{P}=0.40)$. Those sampled from the infested blocks was about the same as those sampled from un-infested blocks (Figure 3).

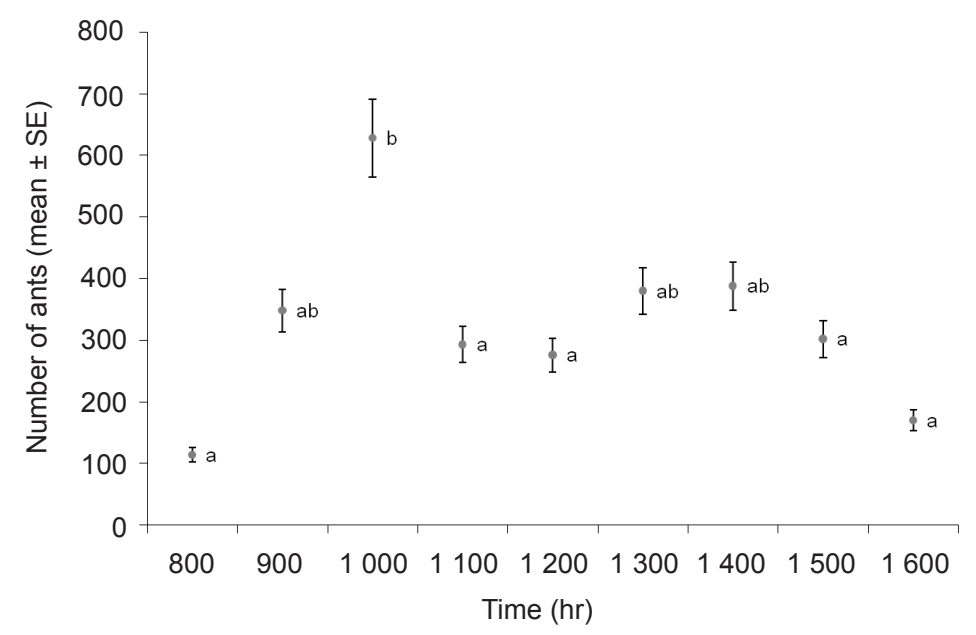

Figure 1. The number $( \pm S E$ ) of little fire ants (LFA) moving about on palm trunks during different times of the day.

(a) Anthesising male inflorescence

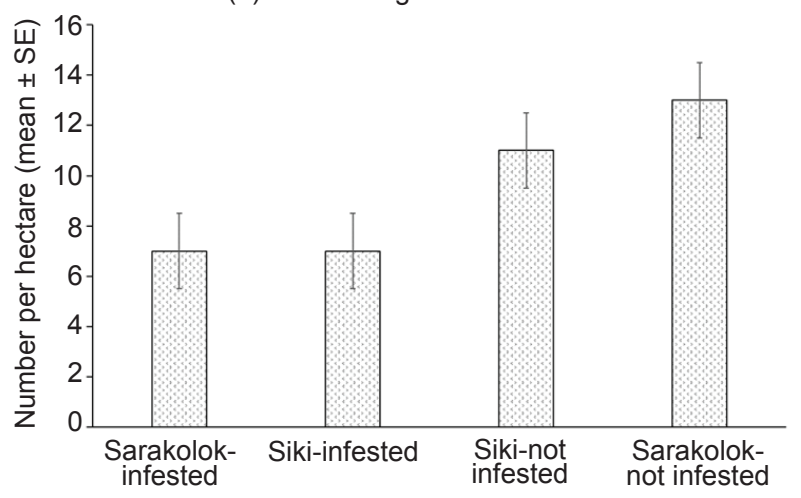

(b) Black fruit bunch

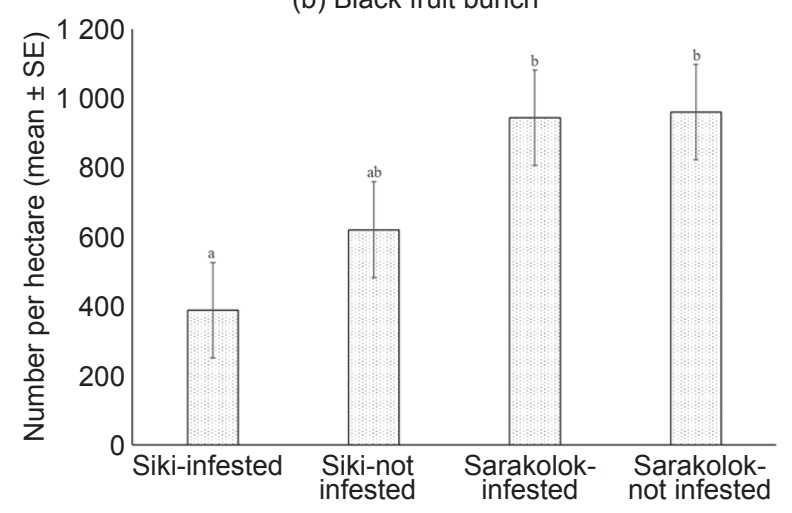

(c) Mixed bunch

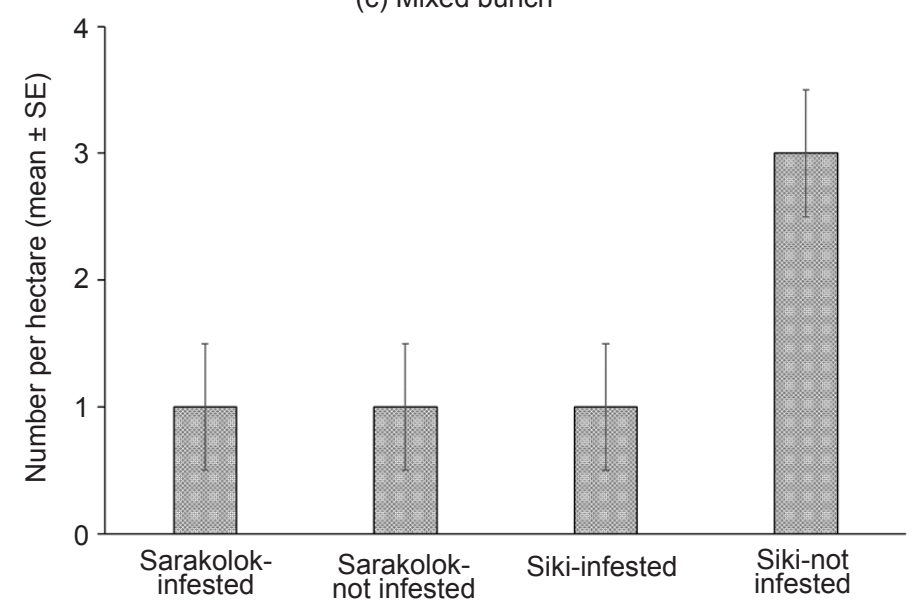

Figure 2. Number (mean $\pm S E$ ) of targeted floral parts sampled over the sampling period from the sampling sites. 


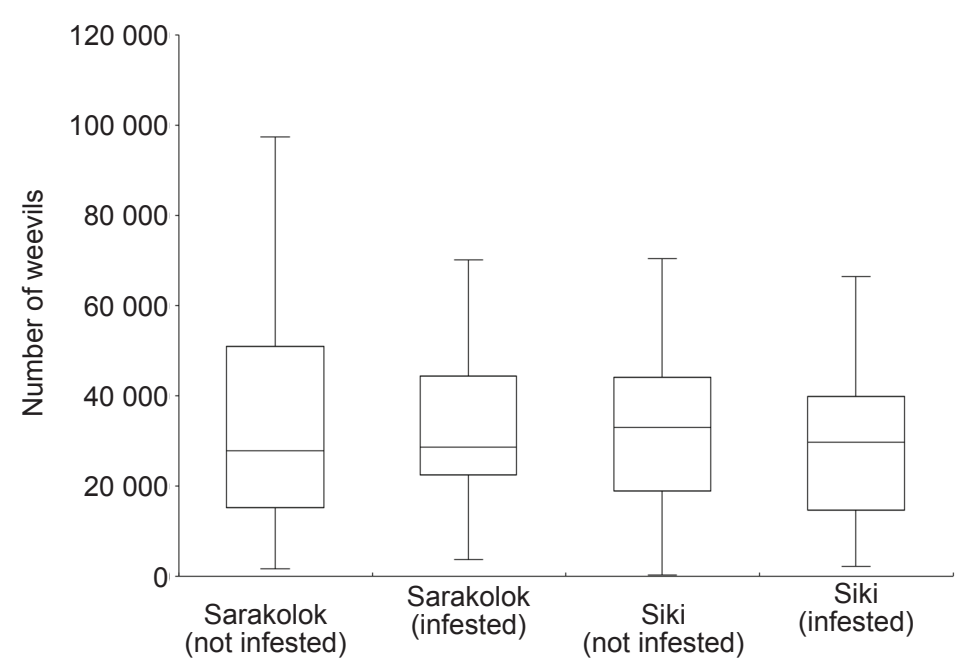

Figure 3. Projected number of pollinating weevil (in thousands) per hectare in blocks sampled (infested vs. not infested).

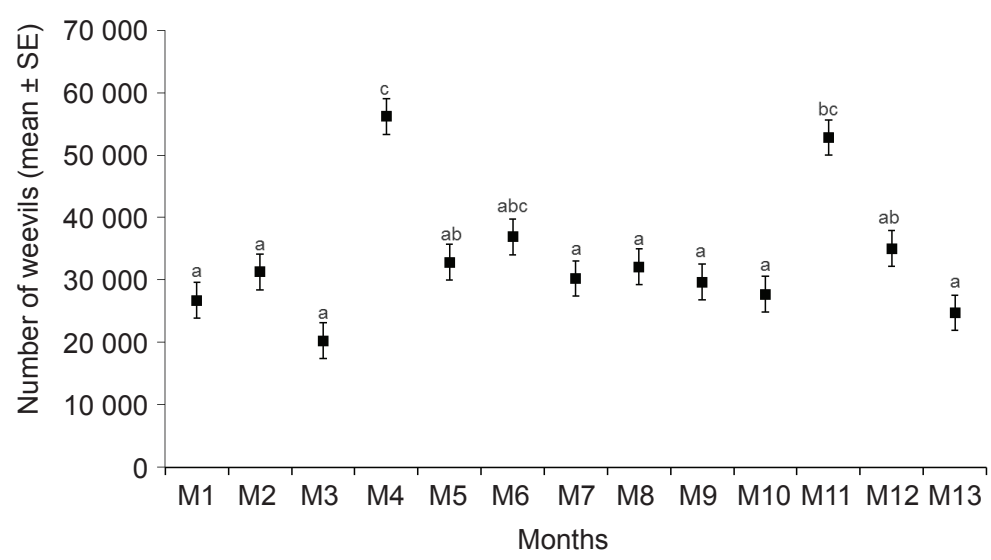

Figure 4. Mean ( \pm SE) number of pollinating weevils (in thousands) sampled per month during the survey period.

Since there was no significant difference in the number of pollinating weevils sampled across the sites, the data was combined to test for any variation in the numbers sampled over time within the 13 months sampling period. The number of weevils sampled during the fourth month was significantly higher than the rest of the months, except the $11^{\text {th }}$ month which did not differ significantly $(F=5.95$, $\mathrm{P}<0.001)$. Those sampled during the rest of the months did not differ significantly (Figure 4).

Despite the ants nesting within close proximity of the breeding substrates (anthesising male spikelets) of the pollinating weevil, the results from this study has shown that they do not impact on the pollinating weevil population with consistently high numbers sampled across blocks and over time. Lack of adequate pollination often results in poor fruit set (mixed and aborted fruit bunches). According to Cik et al. (2013), a minimum of 5000 pollinating weevils per hectare is adequate for effective pollination. The numbers sampled across the sites (both LFA infested and un-infested blocks) and over time during 13 months of the sampling were much higher than the minimum required numbers, thus, pollination was not affected. No mealy bugs and scale insects were observed on black fruit bunches tended by the ants as they were not major pests of the crop.

\section{Evaluation of E. kamerunicus Immature Stage (egg, larva and pupa) Feeding by LFA}

The adult pollinating weevils retrieved from the field exposed spikelets (LFA infested vs. un-infested) did not differ significantly (Table 2), although both differed significantly from those retrieved from the ones set up in the laboratory $(\mathrm{F}=13.97, \mathrm{P}<0.001)$.

TABLE 2. NUMBER OF WEEVILS PER SPIKELET (mean \pm SE) RETRIEVED FROM EXPOSED SPIKELETS

\begin{tabular}{lc}
\hline Treatment & $\begin{array}{c}\text { Number of ants } \\
\text { (mean } \pm \text { SE) }\end{array}$ \\
\hline Field control & $18.73 \pm 1.7 \mathrm{a}$ \\
LFA infested & $24.57 \pm 1.8 \mathrm{a}$ \\
Laboratory control & $35.18 \pm 3.0 \mathrm{~b}$ \\
\hline
\end{tabular}

Note: LFA - little fire ant. 
The external structure of the fresh post anthesis male inflorescences was compact (Figure 5a). When split opened, the eggs and larvae were found concealed within the scales (comprising of the sepals and petals) (Figure 5b). Emergence holes were only created after the adult weevils had exited the spikelets (Figure 5c).

For the direct feeding exposure trial in LFA infested and un-infested sites, all larvae exposed in infested site were killed but were not eaten. The larvae exposed in un-infested site were all eaten by four different species of black predatory ants. Since it was not the intension of this study, the species of predatory ants was not confirmed. No other species of ants were observed at the site infested with LFA.

The lack of impact on the weevil population is due to the physical barrier created by the male floral structure protecting the eggs and larvae from access for predation by the ants rather than them either circumventing the attack or being unpalatable, as the feeding test showed that LFA is able to feed on the weevil larvae. The eggs and the larvae are normally enclosed within the scales (consisting of sepals and petals) of the male flowers. The arrangement of the scales on individual spikelets is closely compact making any intrusion by any invertebrate predators difficult (Figure 5). Exit holes are only created once the adult weevils emerge from the post anthesising spikelets. The adult weevils prevent any predation by flying off immediately after exiting the spikelets.

The lack of presence of other native ant species within the infested site and the presence of four predatory ant species within the site without infestation reaffirmed the invasive nature of the ant. LFA is known to aggressively replace other species of ants within their native range in areas where they invade (Fabres and Brown Jr, 1978).

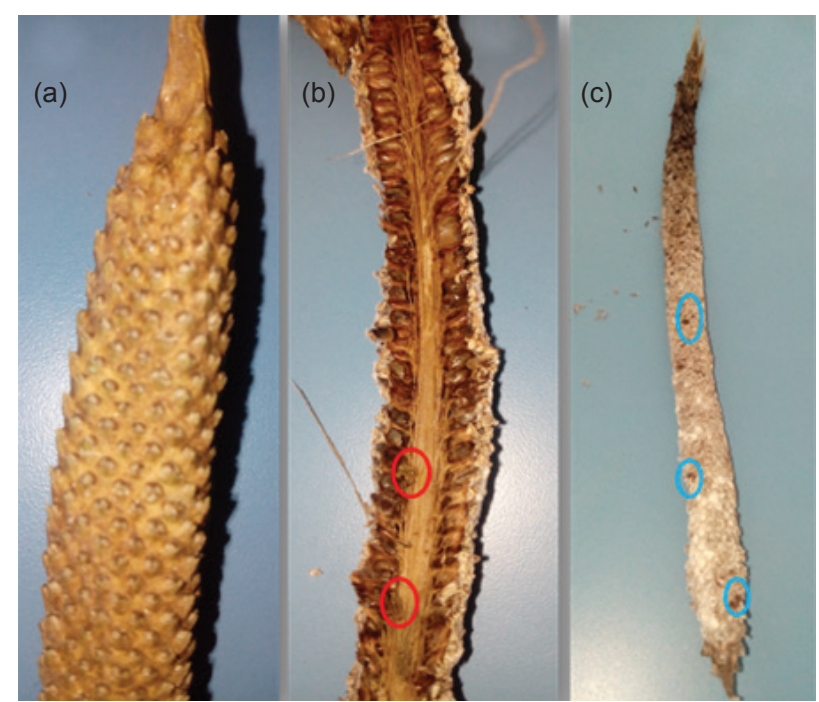

Figure 5. Close up photographs showing (a) the compact structure of male spikelet, (b) pollinating larvae within split spikelet, and (c) the number of weevil exist holes in post anthesising spikelet.

\section{Impact of LFA Sting on Worker Productivity Time}

When stung by LFA, most growers take more than $10 \mathrm{~min}$ to sort out the pain before resuming work. Around $40 \%$ of the growers interviewed indicated that it takes between 30-60 min to get over the pain whilst $20 \%$ highlighted for it to take more than 60 min (Figure 6). The only effective means to overcome the pain is through full shower in water. More than $60 \%$ of the growers indicated of taking full showers after being stung by the ant to get rid of the pain (Figure 7). When water is not available, the growers do not take showers but usually take longer time to overcome the pain before resuming work. They further commented that it is usually more painful when being stung on the eyes sometimes resulting them to terminate work and return home to sort out the pain.

Although the ant does not impact on the pollinating weevil population, it does affect worker productivity time. Cumulatively, the amount of time spent on sorting out the pain can be substantial from repeated stings. Management options need to be considered on approaches that can be applied to skirt the sting.

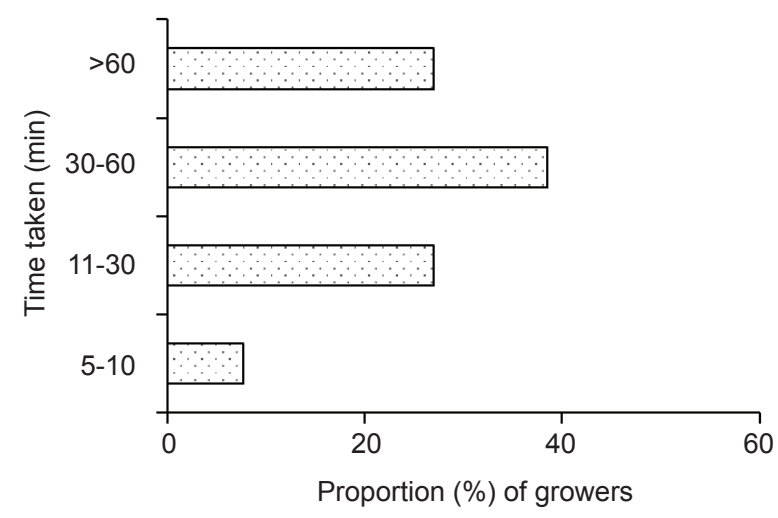

Figure 6. Time (min) taken to overcome pain from little fire ant (LFA) sting against the proportion of growers (respondents).

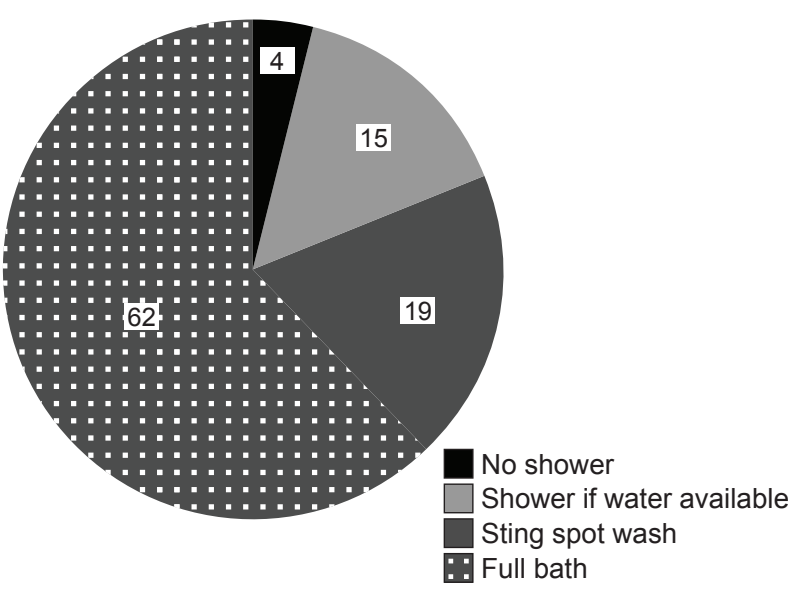

Figure 7. Proportion of growers (respondents) against the measures taken to overcome pain from little fire ant (LFA) sting. 


\section{CONCLUSION}

The LFA population invading the oil palm fields in West New Britain Province is both arboreal and ground dwelling placing them within close proximity of the pollinating weevil breeding substrate (male inflorescences). However, preying on immature stages of the weevil is prevented by the structure of the floral parts on the male spikelets. Whilst the impact on the pollinating weevil population is circumvented, the ant does affect worker productivity in terms of the period of time spent on overcoming the pain from the sting. Management options need to be considered on how best the stinging by the ants can be avoided.

\section{ACKNOWLEDGEMENT}

We would like to thank the Papua New Guinea Oil Palm Research Association (PNGOPRA) Scientific Advisory Committee (SAC) for approval to conduct the research. PNGOPRA Entomology team at Dami Oil Palm Research Station and Hoskins OPIC Project team are acknowledged for assisting with the trials and smallholder grower questionnaire surveys. The anonymous reviewers of the article are indebted for their time.

\section{REFERENCES}

Cik, M R Z A; Noor, H H and Samsudin, A (2013). Role of pollinating weevil (Elaedobius kamerunicus), seasonal effects and its relation to fruit set in oil palm area of FELDA. Proc. of the PIPOC 2013 International Palm Oil Congress. MPOB, Bangi. p. 1-4.

Fabres, G and Brown Jr, W L (1978). The recent introduction of the pest ant, Wasmania auropunctata into New Calendonia. J. Australian Entomological Society, 17: 139-143.

Foucaud, J; Orivel, J; Loiseau, A; Delabie, J H; Jourdan, H; Konghouleus, D; Vonshak, M; Tindo, M; Mercier, D; Fresneau, D; Mikassa, J; McGylnn, T; Mikheyev, A S; Oetler, J and Estoup, A (2010). Worldwide invasion by the little fire ant: Routes of introduction and eco-evolutionary pathways. Evol. Appl., 3(4): 363-374. DOI: 10.1111/j.17524571.2010.00119.

Fournier, D; Estoup, A; Orivel, J; Joudan, H; Le Brenton, J and Keller, L (2005). Clonal reproduction by males and females in little fire ant. Nature, 435(7046): 1230-1234.
Holway, D A; Lach, L; Suarez, A V; Tsutsui, N D and Case, T J (2002). The causes and consequences of ant invasions. Review of Ecology and Systematics, 33: 181233.

Howard, D F; Blum, M S; Jones, $\mathrm{T} H$ and Tomalski, M D (1982). Behavioural responses to an alkylpyrazine from the mandibular gland of the ant, Wasmania auropunctata. Insectes Sociaux, 29: 369374.

Orivel, J; Granigier, J; Foucaud, J; Le Brenton, J; Andres, J; Jourdan, H; Delabie, J H C; Fournier, D; Cerdan, P; Facon, B; Estoup, A and Dejean, A (2009). Ecologically heterogenous populations of the invasive ant, Wasmania auropunctata within its native and introduced ranges. Ecological Entomology, 34: 504-512.

Rey, O; Facon, B; Foucaud, J; Loiseau, A and Estoup, A (2013). Androgenesis is a maternal trait in the invasive ant, Wasmania auropunctata. Proc. of the Royal Society of Biological Sciences, 280(1766): 20131181. DOI:10.1098/rspb.2013.1181.

Showalter, D N; Troyer, E J; Aklu, M; Jang, E B and Siderhurst, M S (2010). Alkylpyrazines: Alarm pheromone components of the little fire ant, Wasmania auropunctata (Roger) (Hymenoptera: Formicidae). Insectes Sociaux, 57: 223-232.

Vanderwoude, C (2008). Operational plan for management of Wasmania auropunctata (little fire ant) in East Sepik Province, Papua New Guinea, Auckland, New Zealand: Unpublished Report.

Vanderwoude, C (2015). Personal communication. Hawaii Ant Lab, Department of Agriculture, Hilo, Hawaii, United States of America.

Vonshak, M; Dayan, T; Ionescu-hirsh, A; Freidberg, A and Hefetz, A (2009). The little fire ant, Wasmania auropunctata: A new invasive species in the Middle East and its impact in the local arthropod fauna. Biological Invasions, 12(6): 1825-1837. DOI 10.1007/ s10530-009-9593-2.

Wetterer, J K (2013). Worldwide spread of the little fire ant, Wasmania auropunctata (Hymenoptera: Formicidae). Terrestrial Arthropod Reviews, 6: 173184.

Wetterer, J K and Porter, S D (2003). The little fire ant, Wasmania auropunctata: Distribution, impact and control. Sociobiology, 1: 1-42. 